\title{
Speculative Prices and Popular Models
}

\author{
Robert J. Shiller \\ The Journal of Economic Perspectives, Vol. 4, No. 2. (Spring, 1990), pp. 55-65.
}

Stable URL:

http://links.jstor.org/sici?sici=0895-3309\%28199021\%294\%3A2\%3C55\%3ASPAPM\%3E2.0.CO\%3B2-I

The Journal of Economic Perspectives is currently published by American Economic Association.

Your use of the JSTOR archive indicates your acceptance of JSTOR's Terms and Conditions of Use, available at

http://www.jstor.org/about/terms.html. JSTOR's Terms and Conditions of Use provides, in part, that unless you have obtained prior permission, you may not download an entire issue of a journal or multiple copies of articles, and you may use content in the JSTOR archive only for your personal, non-commercial use.

Please contact the publisher regarding any further use of this work. Publisher contact information may be obtained at http://www.jstor.org/journals/aea.html.

Each copy of any part of a JSTOR transmission must contain the same copyright notice that appears on the screen or printed page of such transmission.

JSTOR is an independent not-for-profit organization dedicated to and preserving a digital archive of scholarly journals. For more information regarding JSTOR, please contact support@jstor.org. 


\title{
Speculative Prices and Popular Models
}

\author{
Robert J. Shiller
}

$\mathbf{T}$

he rational expectations revolution in economics was born of the recognition that the expectations people hold for future economic variables are fundamental to their behavior. Thus, our (economists') economic models require their (those who make up the economy) economic models, models which they use to generate their expectations. The key idea of rational expectations models is to collapse the two models into one: to assume that people know (or behave as if they know) the true model that describes the economy. This idea allows economists to construct simple and elegant models of the economy, models that are appealing theoretically and that can be studied without collecting any data about the models in the minds of economic actors.

The problem with the rational expectations models is that collapsing the two kinds of models into one is a gross oversimplification. Obviously, the popular models (the models that are used by the broad masses of economic actors to form their expectations) are not the same as those held by economists. Once one accepts the difference, economic modelling cannot proceed without collecting data on the popular models themselves.

This paper reports on such a data collection effort on popular models, using questionnaire survey methods, with the purpose of understanding speculative markets. I will report here on my research to understand the U.S. stock market crash of October 1987; research Fumiko Konya, Yoshiro Tsutsui and I undertook to understand the Japanese stock market crash of October 1987; research Karl Case and I undertook to understand recent real estate booms; and research John Pound and I undertook to understand the periodic "hot" markets for initial public offerings (IPO's) of common stock.

- Robert J. Shiller is Stanley B. Resor Professor of Economics, Cowles Foundation, Yale University, New Haven, Connecticut. 
Two basic questionnaire methods were used to study popular models. A response-coding method begins with broad open-ended questions, to which respondents are asked to fill in their answers in their own words. The questions ask what they think is the cause of certain phenomena in the economy, or how they make decisions related to the phenomena. Respondents often interpret the open-ended questions in unpredictable ways and give answers that are short and impulsive, but the answers do give clues as to what people think. Their answers are coded into categories; the share of respondents who voluntarily mention certain themes (certainly downward-biased measures of the percents who think about such themes) are tabulated.

A trial-model method begins with the same questions posed in informal personal interviews. From this, the interviewer tries to infer what the popular models are, and then frames questionnaire items to ask a new set of respondents directly what they think about the presumed popular models.

The advantage of the response-coding method is that it gives a better quantitative indication of the importance of each popular model in popular thinking, since no ideas are put in respondents' minds. But the popular models respondents freely give are inevitably vaguely defined. The advantage of the trial-model method is that it enables the collection of sharper information about the popular models. By either method, popular models will be described by researchers in terms of the cognition and language of ordinary individuals, not the language of professional economists.

\section{The Stock Market Crash of 1987}

During the week of the stock market crash of October 19, 1987, I sent out 1000 questionnaires to institutional investors and 2000 questionnaires to individual investors, asking them to report "your own personal experiences" during the crash. Questionnaire responses were received from 284 institutional investors and 605 individual investors, Shiller (1989b). Four months later, Fumiko Kon-ya, Yoshiro Tsutsui and I (1989) sent out 114 similar questionnaires about the crash to Japanese institutional investors and received 52 responses.

Using the response-coding method, we asked the investors, "Can you remember any specific theory you had about the causes for the price declines of October 14-19, 1987?" The most common theme among U.S. investors was that the market was overpriced. About a third of both individual and institutional investors wrote this. No consistent explanation was given what "overpriced" means or why the market was overpriced. The second most common theme was an institutional stop-loss theme, identified by key words: institutional selling, program trading, and stop-loss or computer trading. The third most common theme (offered by about a quarter of respondents) was an investor irrationality theme, that investors were crazy or that the fall was due to investor panic or capricious change in opinion.

After this, using the trial-model method, we asked investors to categorize the theory they had just written into "a theory about investor psychology" or "a theory about fundamentals such as profits or interest rates." Two-thirds of the U.S. investors, both individual and institutional, and three-quarters of the Japanese investors chose 
investor psychology. This perhaps gives an indication what people meant who wrote that the market was overpriced.

Investors were asked: "Did you think at any point on October 19, 1987, that you had a pretty good idea when a rebound was to occur?" In the United States, about a third of both individual and institutional investors said "yes," far more than the proportion who traded on October 19. The questionnaire then asked: "If yes, what made you think that you knew when a rebound would occur?" Again, respondents were given a space to write in their own answers. What struck me in reading the answers of U.S. respondents was the frequency with which people wrote "intuition," "gut feeling" or the like.

When respondents went beyond such vague statements the models expressed were usually extremely simple. The most frequently expressed theme among U.S. investors was a notion that large price drops should be followed shortly by a reversal; 37 percent of institutional investors and 14 percent of individual investors mentioned this. Less common was a notion that stock prices had reached such a low level that a price increase was to be expected; 14 percent of the institutional investors and 8 percent of the institutional investors were coded as saying this. Reference to more established theories (like theories about portfolio insurance or technical indicators) were rare here. ${ }^{1}$

It is a striking fact that many investors think that they can forecast the market and some of these are eager to take action. The random walk theory of stock prices now has some currency as a popular model, but other theories are still very much around. Why do some people think that they can forecast the market on a day of a record price drop? Sometimes comparisons with past experience, particularly 1929, were made. But people cannot have learned just from past experience what to expect on October 19, since the one-day drop was of unprecedented magnitude.

I asked U.S. respondents to rate (on a one to seven scale) the importance of various news stories "to you personally on October 19," with the admonition, "please tell how important you then felt these were, and not how others thought about them." I included on the list all of the stories over the past week that seemed to me to be possibly important in the transmission of the crash. I also included as news stories "the 200 point drop in the Dow on the morning of Monday, October 19" and the "drop in U.S. stock prices October 14-16, 1987." While all news stories were granted some importance, no picture emerged as to what "triggered" the crash. What stood out was the news stories about the price drops. The most popular news story among both individual and institutional investors was the 200 point drop that morning; the second most popular story was the price drops on October $14-16 .^{2}$

\footnotetext{
${ }^{1}$ The presence of a large amount of portfolio insurance also played a role in the crash. The popularity of portfolio insurance among institutional investors can be understood only as the response to a new fashion or peculiar popular model. See Shiller (1988).

${ }^{2}$ Merton Miller has pointed out to me that similar conclusions were reached in a Securities and Exchange Commission study about the 6.1 percent one-day drop in stock prices of September 3, 1946. For each interviewee they coded the "major reason" for selling into one of 17 categories. The largest category, coded for 43 percent of interviewees, was "declining prices on September 3." The second largest category coded for 13 percent of respondents was another popular model, "Dow theory" (Securities and Exchange Commission, 1947).
} 
We investigated the emotional environment at the time of the crash by asking respondents if they experienced "any unusual symptoms of anxiety (difficulty concentrating, sweaty palms, tightness in chest, irritability, or rapid pulse) regarding the stock market." On October 19, 23 percent of U.S. individual investors and 43 percent of U.S. institutional investors said yes. On October 20, 42 percent of Japanese investors answered yes. I find these percentages remarkably high, given that the samples were just random samples of all investors. But the anxiety does not necessarily mean that people were "panicking" or performing badly. It might mean that, in a sense, people were unusually alert and that other matters were brushed aside so that careful investment decisions could be made.

From this evidence, we begin to see how popular, intuitive, models of speculative prices informed investor behavior at the time of the crash. The suggestion we get of the causes of the crash is one of people reacting to each other with heightened attention and emotion, trying to fathom what other investors were likely to do, and falling back on intuitive models like models of price reversal or continuation. There appears to be no recognizable exogenous trigger for the crash. With such popular models, a feedback system is created with possibly complicated dynamics, and we do not need to refer to a trigger to explain a crash.

\section{Recent Booms in Real Estate}

Housing prices in California have recently boomed: prices increased around 20 percent between mid-1987 and mid-1988 in many California cities. Karl Case and I (1988) sent 1030 questionnaires to recent home buyers in two California cities, Anaheim (Orange County) and San Francisco. We also sent 500 questionnaires to home buyers in Boston, Massachusetts, where prices had fallen in the real estate market after a major boom a few years earlier, and 500 to Milwaukee, Wisconsin, where the real price of housing had remained nearly unchanged over the preceding five years. We received 886 responses.

The mailing lists were taken at random from public records of closings in May 1988. Since identical questionnaires were sent to the four cities (identical except for changes in the city names that appeared in the questionnaires) and since they were sent at the same time, the differences across cities in the results can be attributed only to lucal real estate conditions.

Using the response-coding method, the home buyers were asked for their theories of what explained recent changes in home prices in their city, and for any events that they thought might have changed the trends in housing prices. We coded the answers into 17 categories.

As with the stock market, we found no exogenous trigger that could be seen as precipitating the price surge. The most common theme in the answers in all four cities was interest rate changes. Since interest rates are virtually the same around the country, these could not explain the sharply different behavior of housing prices in the different cities. 
Not a single person from among the 886 respondents cited any quantitative evidence about future trends in supply or demand, or professional forecasts of future supply or demand. There is a peculiar lack of interest in objective evidence about fundamentals. Instead, there is a resort to cliches or reference to evidence that one could see oneself while driving around the city (like traffic congestion or the racial composition of the population). The price movements are attributed to whatever seems to be the most plausible explanation. Thus, a quarter of Boston respondents referred to the stock market crash of October 1987 but less than 2 percent of respondents in the other cities did. Only in Boston was there a need to explain a sudden drop in real estate prices.

As with the stock market surveys, the home buyers were also asked to classify the theories they had just written. They were asked to specify whether the theory was "about the psychology of home buyers and sellers" or "a theory about economic or demographic conditions, such as population changes, changes in interest rates, or employment growth (decline)." In all four cities, less than a quarter picked the psychology. The popular model of housing prices tends not to emphasize the psychology of other investors, as does the popular model of the stock market crash.

Our survey revealed that speculative considerations were a prime motive for buying homes in boom cities. For example, 75 percent of our California respondents agreed with the statement: "Housing prices are booming. Unless I buy now, I won't be able to afford a home later," while only 28 percent of our Milwaukee respondents agreed.

It is peculiar, then, that there is so little apparent interest in quantitative evidence about fundamentals. There is instead a feeling in most cities that housing prices cannot decline. Respondents were asked to specify whether buying a home in their city involves "a great deal of risk," "some risk," or "little or no risk." The majority in the boom cities (63 percent in Anaheim and 56 percent in San Francisco) picked little or no risk. The theory that price movements are due to "economic or demographic conditions, such as population changes, changes in interest rates, or employment growth (decline)" would not itself seem to suggest that prices cannot decline. Anyone who reads newspapers carefully would know that home prices in Houston recently dropped 24 percent in two years. In Boston, where housing prices were reported to have declined in 1987, only 36 percent thought buying a home involves "little or no risk." The impression that housing prices cannot decline seems to be a local phenomenon, related to local rather than national experience.

There is evidence of emotional involvement in boom cities, much as we saw with the stock market crash. Of our California respondents, 55 percent agreed, "There has been a good deal of excitement surrounding recent real estate price changes. I sometimes think that I may have been influenced by it." Only 21.5 percent of our Milwaukee respondents agreed. In California, 51 percent of our respondents said that they talked about the housing market frequently with friends, while only 20 percent of the Milwaukee respondents said so.

One of the most common responses in California to our open-ended question asking for what explains recent changes in home prices was that the region is a good 
place to live. This was volunteered by 17 percent our California respondents. But California has always been a good place to live. They are explaining changes in prices with an unchanging variable, which is suggestive of a "shortage illusion."

The shortage illusion in any market is that price changes will not tend to restore equilibrium in the market. Shortages (or surpluses) are seen as continuing indefinitely, and perhaps also price increases (or decreases) are seen as continuing indefinitely, so that observing excess demand may help to reinforce a boom. It seems that the popular model takes shortages or surpluses as reflecting absolute supply and demand, rather than supply and demand at a given price. Disequilibrium is not seen at all as a reflection of a barrier to price adjustment.

Respondents in our boom cities tended to think that the same sort of price increases seen in the last year would continue indefinitely. Anaheim respondents expected an increase of 15 percent in the succeeding year and 14 percent on average for each of the succeeding ten years. In San Francisco, the corresponding price increases were 13 percent and 15 percent. (The corresponding price increase expectations were in the 6 percent to 9 percent range in Boston and Milwaukee). We asked our respondents:

In a "hot" real estate market, sellers often get more than one offer on the day they list their properties. Some are even over the asking price. There are also stories about people waiting in line to make offers. Which is the better explanation?

- There is panic buying, and price becomes irrelevant.

- Asking prices have adjusted slowly or sluggishly to increasing demand.

In the cities that had experienced recent housing price increases, the majority picked the first answer. In San Francisco, 71 percent of those answering picked the first, in Anaheim the figure was 73 percent, in Boston the figure was 61 percent. Now they really made an absurd choice; surely price is not "irrelevant." To an economist, the second choice is true almost as a tautology, given that prices have increased and that there is excess demand.

Only 35 percent of those answering picked the first answer in Milwaukee, where no major housing price increases have occurred recently. This striking difference across cities in answers to a question that is not specific to any city shows that the popular models are themselves influenced by recent experience, and indeed heavily influenced by the local market experience. This difference in perception across cities is useful to bear in mind in considering the possible reasons why speculative bubbles appear to be local phenomena, occurring in one city and not in another relatively nearby city. The difference also shows that part of the dynamics of speculative price changes may be changes in the popular models.

The misinterpretation by the public of excess demand is a factor in the transmission process of price increases. When prices increase, some proportion of sellers will make the mistake of failing to adjust up their asking price enough, and so some houses will sell for more than the asking price ( 8 percent of the houses in our California 
sample, while 59 percent went below asking). If the shortage illusion is operative, this phenomenon may serve to increase demand further. This is a possible link in the vicious circle of a speculative bubble; not only might price increases themselves serve to increase demand, but the appearance of excess demand might serve to increase demand, too.

\section{Underpricing of Initial Public Offerings (IPO's)}

In February 1987, John Pound and I sent out 1500 questionnaires to IPO investors and received 153 responses. In July 1989 I sent out 800 questionnaires to wealthy individuals and institutional investors and received 273 responses.

We undertook these surveys to try to understand why the IPO market shows very high initial returns and why the market goes in and out of "hot" periods. These phenomena in the IPO market have been just as puzzling as the stock market crash or the real estate bubbles discussed above. Prices of IPO's have shown a striking tendency to jump up dramatically as soon as the after-market trading begins. Roger Ibbotson, Jody Sindelar and Jay Ritter presented data that between 1977 and 1987 the average initial return - that is, percentage return from the offering price to the end-of-the-first-day bid price-was 20.25 percent. This is not an annualized rate; it is the actual average increase in value over, generally, no more than a few days. Moreover, periods of high initial returns tend to come and go. For example, they report that the years 1977 through 1980 were all years of above average, and gradually increasing, initial returns, culminating in an average initial return of 49.36 percent in the "hot" market of 1980. Other such "hot" markets, peaking in 1961 and in 1968, are also in evidence. Volume of new issues appears to lag initial returns by six to twelve months (Ibbotson, Sindelar and Ritter, 1988).

It should be borne in mind that investors as a whole cannot expect to claim these dramatic initial returns by buying all IPO's; one is prevented from doing so. One depends on a broker to allocate shares in an offering, and the broker's willingness to do so is likely to be related to the other business that one gives the broker. Still, it is puzzling why this underpricing that causes the high initial returns occurs at all, and why issuing firms will deal with underwriters who substantially underprice issues.

Using the response coding method, IPO investors were asked to explain the theory that led them to purchase a particular IPO. The most common answer was just some description of the product of the company or the "concept" of its strategic plan. They were asked to describe their theory as "a theory about the kinds of stocks that are becoming attractive to investors" or "a theory about fundamentals such as profits or dividends." The former was selected by 57 percent of respondents. As with the stock market crash respondents, investor psychology is very much on the minds of respondents. Whether or not "hot" markets are indeed fads, investors themselves think there are fads in these markets, contrary to the assumption of the rational expectations models in the literature. 
Respondents were asked in 1989: "Can you remember a time in the past 10 years when you became substantially discouraged about investing in initial public offerings in general?" Among those in the sample who had ever bought IPO's, 40 percent of individual investors and 56 percent of institutional investors said yes, and 31 percent and 40 percent respectively said yes in answer to a question where "encouraged" was substituted for "discouraged." The followup questions were: Can you state what discouraged (encouraged) you, and what were your information sources? While answers were quite varied and difficult to classify, response coding revealed that about half of the respondents appeared to be referring to past price changes in stating their reasons: price drops caused them to be discouraged and price increases to be encouraged. Thus, waves of enthusiasm for IPO's appear to be related to interpretations of what other investors are thinking and to evidence on this from observed price movements.

But why are IPO's underpriced on average? Why don't underwriters price issues to clear markets? I have argued (1989a) that the underpricing reflects more than just the asymmetric information theory that the underpricing is compensation for the winner's curse for those who get allocations (Rock, 1986) or the litigation theory that underpricing reduces the probability that underwriters will be sued by investors (Tinic, 1988). Underpricing tends to occur on average for several other reasons. For one, there appears to be a common idea that IPO investors are serving underwriters by buying IPO's and not selling them for a while, providing a "home" and a stable price for the issue and thereby ultimately inducing other investors to reduce their fears about the issue. The high initial return is viewed by many as a payment from underwriters to investors for restricting their selling. For another, there appears to be an idea that underwriters should charge "fair" prices for issues, even when they could obtain a lot more, but underwriters can expect to be repaid for selling at below-market prices by subsequent business from those who obtained allocations in underpriced issues. The high initial return helps investors maintain appearances. I will emphasize here, however, a third theory for underpricing of issues, which I will call the impresario hypothesis.

Impresarios who manage musicians and other entertainers know that the public interprets empty seats in an auditorium as reflecting badly on the performer, and that a jam-packed auditorium is interpreted as evidence that the performer is very much in the public favor. (Again, this is the shortage illusion.) Thus, impresarios know that they should not always price tickets to an event so as to maximize profits on that single event. To do so runs the risk that the event will be undersubscribed. It is often better to create an excess demand for the tickets, creating scenes of people standing in long lines for tickets, or trading among themselves at higher prices. This impression will tend to produce greater demand for subsequent events. By the same token, underpricing IPO's will create the high initial returns that leave the impression that the stockbroker or underwriter is giving good investment advice. By this theory, "hot" markets appear when some salesmen for IPO's discover that some segment of the public is ripe for a "fad" for IPO's. Underwriters then let the high initial returns run for a while to generate publicity and good will for the IPO's. 
A substantial fraction of both wealthy individuals and institutional investors openly admit that they interpret initial returns in accordance with the impresario theory. They were asked: "Imagine you buy shares in an initial public offering recommended you by a broker and the price jumps $15 \%$ on the first day making you a very nice profit for one day. Which statement best describes how this would change your opinion of this broker's (with his/her advisors) investment savvy or ability to pick investments whose market price would increase?" Forty-seven percent of individual investors and 28 percent of institutional investors chose either "strong evidence" or "positive evidence" of ability.

Our survey documented that while IPO investors tend to describe themselves as actively picking IPO's, they showed a strong concern with the reputation of the underwriter and stockbroker for helping them do this. Of the respondents, 57 percent said they would be more likely to buy an IPO that is underwritten by a particular investment bank or investment bank consortium. It is plausible that reputation of their advisors should matter, since IPO investors generally do not do careful research. Only 26 percent of the IPO investor sample said they had done any calculations of what true fundamental value of a share in the company was, and compared the price of a share with this value. IPO investors were generally repeat purchasers of IPO's and communicated extensively with others about IPO's, so that the reputation of the underwriter may well have an effect on subsequent underwriter profits.

Each issuing firm would rather that underwriters did not underprice its issue, but may find that it has no good alternative to dealing with firms that have a policy of underpricing; underwriters without this policy would have so much lower reputation that the price at which the issue could be sold would be even lower.

The impresario hypothesis does not imply that underwriters have any solid control over investor enthusiasm. Any given underwriter probably cannot expect to promote a fad, and certainly not repeatedly, but may find it profitable to follow a standard policy of underpricing. Each "hot" market for IPO's is somewhat concentrated in a certain class of industries and a certain group of underwriters (Ritter, 1984). The 1980 hot market was dominated by Denver area underwriters of natural resource stocks. The 1983 hot market was dominated by different underwriters and by "high tech" stocks. Popular models vary from time to time, and only in certain situations are investors ready to believe and act enthusiastically on IPO investing.

\section{Conclusion}

The research on popular models reported here offers glimpses of the thought processes that underlie speculative booms and crashes. I think that the picture that begins to be revealed is a complicated one-not like any of the simple stories that have been told of speculative bubbles. While the popular models are often unsophisticated, there is a lot to be described about them. By analogy, one might note that to describe a so-called "primitive" language one must define many thousands of words and an elaborate grammatical system, a system that cannot be described without 
recourse to a network of rules and exceptions. Like languages, systems of popular models are learned through years of common discourse. Investing is an activity that generates a great deal of popular conversation and popular media attention.

The three case studies of research on popular models discussed above-the stock market crash, real estate boom, and IPO underpricing cases - illustrate this complexity, in revealing how popular models differ across speculative markets and through time. At the same time, the case studies are also suggestive of some common tendencies among popular models.

For example, investors often thought that investor psychology was what was driving markets, although the incidence of this popular model was much lower in real estate markets. Apparently, certain market characteristics encourage the proliferation of this popular model.

As another example, the shortage illusion tends to arise in all real estate markets, but with substantially lower frequency in a market that has not undergone a boom in recent memory. Apparently the experience of a local real estate boom inclines people to a popular model that is responsible for the illusion.

Further research along these lines might accomplish a number of things. First, research can clarify and elaborate on the popular models already described here. All we have done here is tabulate responses to a few short questions. Different questions on the same topic may produce different answers. Wordings of questions may matter and circumstances may matter. Moreover, respondents may not mean what we think they mean and do not always answer truthfully. Economists can learn about what they really think by careful detective work using the same methods used here. As more data is collected along these lines, misinterpretations of their answers can be revealed by an apparent inconsistency in answers.

Second, further research can look at models at work in other situations, besides the very dramatic boom and bust situations studied here. People may have very different popular models in other times and markets.

Third, further research can look at how popular models change through time, how they diffuse through the population and how such changes are related with time series data on tangible economic variables. 


\section{References}

Case, Karl E., and Robert J. Shiller, "The Behavior of Home Buyers in Boom and Post Boom Markets," New England Economic Review, November/December 1988, 29-46, reprinted in Robert Shiller, Market Volatility. Cambridge: M.I.T. Press, 1989, pp. 404-431.

Case, Karl E., and Robert J. Shiller , "The Efficiency of the Market for Single Family Homes," American Economic Review, March 1989, 79, 125-137.

Ibbotson, Roger G., Jody L. Sindelar, and Jay R. Ritter, "Initial Public Offerings," Journal of Applied Corporate Finance, Summer 1988, 1, 37-45.

Ritter, Jay R., "The 'Hot Issue' Market of 1980," Journal of Business, April 1984, 57, 215-40.

Rock, Kevin, "Why New Issues Are Underpriced," Journal of Financial Economics, January/ February 1986, 15, 187-212.

Securities and Exchange Commission, Trading and Exchange Division, A Report on Stock Trading on the New York Stock Exchange on September 3, 1946, reproduced, Securities and Exchange Commission, Washington, August 21, 1947.

Shiller, Robert J., "Portfolio Insurance and Other Investor Fashions as Factors in the 1987 Stock Market Crash." In Fischer, Stanley, ed., NBER Macroeconomics Annual 1988. Cambridge: National Bureau of Economic Research, 1988.

Shiller, Robert J., "Initial Public Offerings: Underpricing and Investor Behavior," unpublished paper, Yale University, 1989a.

Shiller, Robert J., Market Volatility. Cambridge: M.I.T. Press, 1989b.

Shiller, Robert J., Fumiko, Kon-ya, and Yoshiro Tsutsui, "Investor Behavior in the October 1987 Stock Market Crash: The Case of Japan," Yale University, 1989, and forthcoming in The Journal of Japanese and International Economics.

Tinic, Seha M., "Anatomy of Initial Public Offerings of Common Stock," Journal of Finance, September 1988, 43, 789-822. 
http://www.jstor.org

\title{
LINKED CITATIONS \\ - Page 1 of 1 -
}

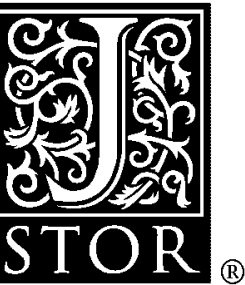

You have printed the following article:

\section{Speculative Prices and Popular Models}

Robert J. Shiller

The Journal of Economic Perspectives, Vol. 4, No. 2. (Spring, 1990), pp. 55-65.

Stable URL:

http://links.jstor.org/sici?sici=0895-3309\%28199021\%294\%3A2\%3C55\%3ASPAPM\%3E2.0.CO\%3B2-I

This article references the following linked citations. If you are trying to access articles from an off-campus location, you may be required to first logon via your library web site to access JSTOR. Please visit your library's website or contact a librarian to learn about options for remote access to JSTOR.

\section{References}

\section{The Efficiency of the Market for Single-Family Homes}

Karl E. Case; Robert J. Shiller

The American Economic Review, Vol. 79, No. 1. (Mar., 1989), pp. 125-137.

Stable URL:

http://links.jstor.org/sici?sici=0002-8282\%28198903\%2979\%3A1\%3C125\%3ATEOTMF\%3E2.0.CO\%3B2-E

\section{The "Hot Issue" Market of 1980}

Jay R. Ritter

The Journal of Business, Vol. 57, No. 2. (Apr., 1984), pp. 215-240.

Stable URL:

http://links.jstor.org/sici?sici=0021-9398\%28198404\%2957\%3A2\%3C215\%3AT\%22IMO1\%3E2.0.CO\%3B2-O

\author{
Anatomy of Initial Public Offerings of Common Stock \\ Seha M. Tiniç \\ The Journal of Finance, Vol. 43, No. 4. (Sep., 1988), pp. 789-822. \\ Stable URL: \\ http://links.jstor.org/sici?sici=0022-1082\%28198809\%2943\%3A4\%3C789\%3AAOIPOO\%3E2.0.CO\%3B2-J
}

